\title{
A systematic review of the case findings, testing and
}

\section{management of COVID-19 [version 1; peer review: 1 approved}

\section{with reservations]}

\author{
Dewi Susanna (D1), Dian Pratiwi2, Sang Gede Purnama3,4 \\ ${ }^{1}$ Department of Environmental Health, Faculty of Public Health, Universitas Indonesia, Depok, Jawa Barat, 16424, Indonesia \\ ${ }^{2}$ Alumni of Faculty of Public Health, Universitas Indonesia, Depok, Jawa Barat, 16424, Indonesia \\ ${ }^{3}$ Faculty of Medicine, Udayana University, Denpasar, Bali, 80234., Indonesia \\ ${ }^{4}$ Doctoral Program in Faculty of Public Health, Universitas Indonesia, Depok, Jawa Barat, 16424, Indonesia
}

V1 First published: 12 May 2021, 10:377

https://doi.org/10.12688/f1000research.50929.1

Second version: 02 Feb 2022, 10:377

https://doi.org/10.12688/f1000research.50929.2

Latest published: 08 Aug 2022, 10:377

https://doi.org/10.12688/f1000research.50929.3

\section{Abstract}

Background: Mass testing and adequate management are essential to terminate the spread of coronavirus disease 2019 (COVID-19). This testing is due to the possibility of unidentified cases, especially ones without COVID-19 related symptoms. This review aimed to examine the outcome of the existing studies on the ways of identifying COVID19 cases, and determine the populations at risk, symptom and diagnostic test management of COVID-19.

Methods: The articles reviewed were scientific publications on the PubMed, Science Direct, ProQuest, and Scopus databases. The keywords used to obtain the data were COVID-19, severe acute respiratory syndrome coronavirus 2 (SARS-CoV-2) and case detection, case management or diagnostic test. We applied the Preferred Reporting Items for Systematic Reviews and Meta-Analyses (PRISMA) and Population, Intervention, Control and Outcomes (PICO) approaches.

Results: A total of 21 articles from 13 countries met the inclusion criteria and were further analyzed qualitatively. However, $62 \%$ of the articles used a rapid antibody test for screening rather than a rapid antigen test. According to the rapid antigen test, 51.3\% were positive, with men aged above 50 years recording the highest number of cases. Furthermore, $57.1 \%$ of patients were symptomatic, while diagnostic tests' sensitivity and specificity increased to $100 \%$ in 14 days after the onset.

Conclusions: Real-time polymerase chain reaction (RT-PCR) is recommended by the World Health Organization for detection of COVID-19. Suppose it is unavailable, the rapid antigen test is used as an alternative rather than the rapid antibody test. Diagnosis is

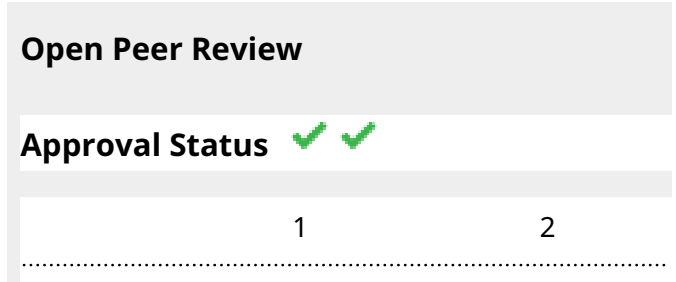

version 3

(revision)

08 Aug 2022

version 2

(revision)

02 Feb 2022

version 1

12 May 2021

\section{Sonu Menachem Maimonides Bhaskar (iD,}

Liverpool Hospital, Liverpool, Australia

Ingham Institute, Liverpool, Australia

Global Health Neurology Lab and NSW Brain

Clot Bank, Sydney, Australia

2. Rahayu Lubis ID, Global Health Neurology

Lab and NSW Brain Clot Bank, Sydney,

Australia

Any reports and responses or comments on the article can be found at the end of the article. 
expected to be confirmed using the PCR and serological assay to achieve an early diagnosis of COVID-19, according to disease progression, gradual rapid tests can be used, such as rapid antigen in an earlier week and antibody tests confirmed by RT-PCR and serological assay in the second week of COVID-19.

Keywords COVID-19, SARS-CoV-2, case detection mechanism, case finding, case management, diagnostic test

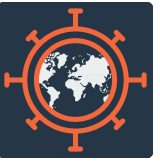

This article is included in the Emerging Diseases

and Outbreaks gateway.

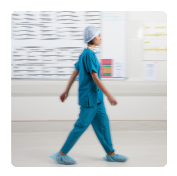

This article is included in the Health Services

gateway.

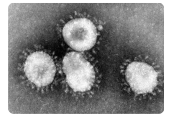

This article is included in the Coronavirus

collection.

Corresponding author: Dewi Susanna (dsusanna@ui.ac.id)

Author roles: Susanna D: Conceptualization, Funding Acquisition, Methodology, Supervision, Visualization, Writing - Review \& Editing; Pratiwi D: Data Curation, Investigation, Resources, Visualization; Purnama SG: Data Curation, Writing - Original Draft Preparation, Writing - Review \& Editing

Competing interests: No competing interests were disclosed.

Grant information: The work was supported by the Directorate of Research and Development Universitas Indonesia through Grant No. NKB-2605/UN2.RST/HKP.05.00/2020.

The funders had no role in study design, data collection and analysis, decision to publish, or preparation of the manuscript.

Copyright: $\odot 2021$ Susanna D et al. This is an open access article distributed under the terms of the Creative Commons Attribution License, which permits unrestricted use, distribution, and reproduction in any medium, provided the original work is properly cited.

How to cite this article: Susanna D, Pratiwi D and Purnama SG. A systematic review of the case findings, testing and management of COVID-19 [version 1; peer review: 1 approved with reservations] F1000Research 2021, 10:377

https://doi.org/10.12688/f1000research.50929.1

First published: 12 May 2021, 10:377 https://doi.org/10.12688/f1000research.50929.1 


\section{Introduction}

The outbreak of severe acute respiratory syndrome coronavirus 2 (SARS-CoV-2) is known as coronavirus disease 2019 (COVID-19). This outbreak started in Wuhan Hubei, China, in early December $2019^{1}$. Presently, an exponential increase in infection cases has been continuously reported in various countries, although vaccinations now accompany this.

Coronaviruses are a group of RNA viruses that cause various respiratory, gastrointestinal, and neurological diseases with mild and severe symptoms in humans and animals. There are at least two types with severe symptoms: Middle East respiratory syndrome (MERS) and severe acute respiratory syndrome (SARS). COVID-19, which SARS-CoV-2 causes, is a new type of disease that humans have never identified before. Furthermore, it is regarded as a zoonotic disease (an animal disease transmitted to humans). SARS has been reported in several studies to be transferred from civets to humans while MERS is contacted from camels. Meanwhile, the particular animal source of COVID-19 transmission is still unknown ${ }^{2}$.

The governments of various countries have created several services to handle and prevent the spread of COVID-19. Furthermore, several steps have been taken, such as the rapid purchase of test kits, additional health facilities to accommodate patients, laboratories capable of examining blood specimens, human resources, equipment, infrastructure, etc. It is presumed that these additions can suppress the number of positive cases. Patients with symptoms are immediately tested and treated or even monitored; however, the number of positive cases is still increasing.

The strategies for the prevention and control of COVID-19 include increasing epidemic surveillance, quarantining the infection source, speeding up the diagnosis of suspected cases, optimizing close contact management, constricting the prevention and control of outbreaks. The strategies also prevent possible epidemic rebounds by immediate quarantine of individuals in close contact of positive cases and strengthening community prevention and control measures ${ }^{3}$. However, early and accurate case findings are necessary to maximize these efforts. Therefore, it is important to review the results of existing studies on finding cases, determine the population at risk, determine diagnostic tests, and provide facilities including human resources and tools to prevent Covid-19 transmission to ending this pandemic.

Due to the influence of COVID-19, several studies have recently been conducted because the pandemic is complex in many aspects of life ${ }^{4-6}$. The complexity is attributed to the crises experienced in the national health, economic, education, cultural, sports, and social systems ${ }^{6}$, apart from the drug and vaccine candidates ${ }^{5}$. The occurrence and development of SARS-CoV-2 depend on the interaction between the virus and the individuals' immune system ${ }^{7}$. Therefore, its treatment requires special analyses for case findings and management of COVID-19 cases. Presently, there is a controversy over the use of rapid tests and screening for new cases. For instance, Indonesia's government is yet to decide whether rapid tests need to be continued or stopped.
This review aimed to examine the outcome of the existing studies on the ways of identifying COVID-19 cases, determining the populations at risk, symptom and diagnostic test management of COVID-19.

\section{Methods}

A systematic review was conducted to identify articles that describe the diagnostic, identification, and management of SARS-CoV-2 and COVID-19 cases. The review is reported following the Preferred Reporting Items for Systematic Reviews and Meta-Analyses (PRISMA) guidelines ${ }^{8}$.

\section{Ethical approval}

This review received ethical approval from the Research and Community Engagement Ethical Committee of Faculty of Public Health, Universitas Indonesia Number: Ket-198/UN2.F10. D11/PPM.00.02/2020.

\section{Inclusion criteria and exclusion criteria}

Original studies published in open-access journals before 1 August 2020 in English during the COVID-19 pandemic were included. Studies had to include rapid COVID-19 tests and screening. Closed access articles, audio, communication, reviews, reports, perspectives, case studies, surveys, clinical and molecular papers, mathematical modelling, and diagnostic procedures were excluded from this review.

\section{Search strategy}

A systematic search was conducted in four databases, specifically SCOPUS, Science Direct, ProQuest and PubMed. The keywords used to obtain data from Science Direct included COVID-19/COVID/coronavirus 2019 OR SARS-CoV-2 AND rapid test OR rapid diagnostic test AND screening.

For Scopus, the following search was used: ((TITLE-ABS-KEY (covid-19) OR TITLE-ABS-KEY (covid) OR TITLE-ABSKEY (coronavirus 2019) OR TITLE-ABS-KEY (sars-cov-2) AND TITLE-ABS-KEY (rapid AND test) OR TITLE-ABSKEY (covid AND diagnostic AND test) AND TITLE-ABS-KEY (screening)).

The search used for Science Direct was "COVID-19" OR COVID OR "coronavirus 2019" OR "SARS-CoV-2" AND ("rapid test" OR "rapid diagnostic test") screening. The ProQuest used covid-19 OR covid OR (coronavirus 2019) OR (sars-cov-2) AND (rapid test) OR (rapid diagnostic test) AND (screening).

The search used for PubMed was ((( (covid-19) OR (covid) OR (coronavirus 2019) OR (SARS-CoV-2)) AND (rapid test)) OR (rapid diagnostic test)) AND (screening)))).

\section{Study selection}

The initial screening was conducted for articles between 1 December 2019 and 31 July 2020. All the authors recorded and reviewed the collected articles. Furthermore, DS determined the study design, time frame, and criteria for the included studies to retrieve the articles and process the data. Importantly, DS retrieved the data from SCOPUS and Science Direct databases, while DP from ProQuest and PubMed databases 
as SGP's suggestion. The identified articles' information was imported into Excel worksheets and Mendeley Desktop, where duplicates between databases were removed. DS, DP, and SGP separately reviewed the titles to eliminate analysis that does not meet the inclusion criteria before reviewing the title and the abstract. Moreover, DS and DP accessed the full-text articles for the eligibility criteria. In case there were differences in the number of articles obtained, the two authors re-checked the articles again using the same criteria until the same articles are selected. The final decision of articles included was after DS and DP. All authors discussed the variables to assess the full paper using PICOS to determine the study questions. The PICOS's assessment used include 1) Population, 2) Intervention: The diagnostic tests for COVID-19, 3) Comparison: the method of the test and antigen or antibody results, and 4) Outcome: The antibody or antigen tests. Any discrepancies were resolved through consensus via a virtual meeting.

Quality assessment for the selected articles was performed using a modified checklist ${ }^{9}$ that consisted of seven questions. If the answer of the question is 'yes', the value will be ' 1 ', while if the answer is 'no', the value will be ' 0 '. Each article will have a total value, then scored (in \%) by calculating the total value divided by the total number of question, then multiplied by 100 .

The score grouped into three scoring (in \%) = total score divided by the total number of question, then multiplied by 100 ; then categorized as 'good' (68-100\%), satisfactory (34-67\%), and bad (0-30\%), as shown in Table 1 (as an attachment).

\section{Data extraction}

All authors designed the variables to be described in the matrix and the topics discussed. The differences in the case detection method of the articles could be a source of bias. To minimize the biases, this review determined and selected the same variables (screening, symptoms, and diagnostic tests; at least an article had one of the following epidemiological parameters regarding COVID-19 or SARS-CoV-2: (i) signs and symptoms, (ii) types of test, (iii) case findings, (iv) screening and testing for COVID-19, (v) procedures for managing positive cases, or (vi) interventions or treatments.). The diagnostic test of each article was different after-time onset. Therefore, the authors used the limit after onset both less and more than 14 days (after onset $\leq 14$ days and $>14$ days).

\section{Data analysis}

The outcome of the analysis was displayed in a matrix containing the author's name, title, date of research, country of origin of the article, method, and results. Another table included the symptoms, incubation period, method of case finding, diagnostic tests, and type of examination in a more detailed manner. Management identification was based on the type of intervention, care, and treatment.

Descriptive synthesis conducted in the textual description of findings and presented in all tables. A narrative synthesis was undertaken for analysis based on the topics selected. The issues raised included high-risk group, case findings, symptoms of COVID-19 patients, diagnostic test, and the potential strengths and weaknesses of this review, are shown in Table 1. The average quality score was $87.1 \%$ and ranged from $71.4 \%$ to $100 \%$.

\section{Results}

Based on the four databases, 152 titles were obtained, with 21 studies included in the review. Figure 1 provides an overview of the articles included. There were 21 eligible articles conducted between December 2019 and 31 July 2020 from 13 countries, including France, the United States of America, Italy, Singapore, Chile, Germany, Taiwan, South Korea, Austria, Bulgaria, Japan, Spanish, and Brazil (Table 2).

Each country has its reasons and policies for adopting the coronavirus screening method. Besides polymerase chain reaction (PCR), antigen and antibody tests, there are various tests for detecting the virus, such as the use of clinical immunoassays. An immunoassay is a biomedical test for measuring molecules' presence in a solution through the use of antibodies or antigens ${ }^{10}$.

A rapid test is the screening method for detecting COVID-19 that shows the results quickly, specifically between a few minutes to a maximum of one hour. The methods in Table 3 are divided into two, namely the antigen and antibody rapid tests. The rapid antigen test is used to detect a viral protein (antigen) and is detected when the virus is actively replicating. Conversely, the rapid antibody test is used to detect antibodies or immunoglobins produced by the body against the virus. According to Table 3, showing the screening tests used in the studies, $62 \%$ of the articles (13/21) adopted the rapid antibody and antigen tests, for mostly males aged over 50 years. The rapid antigen test results showed that $51.3 \%$ were positive, as shown in Table 3.

The terms for COVID-19 patients are divided into several groups, namely patients under monitoring or confirmed cases without symptoms ${ }^{11}$. The clinical manifestations of COVID-19 patients have a broad spectrum, ranging from lack of symptoms to mild illnesses, pneumonia, severe pneumonia, and septic shock. In Table 4, the symptoms were divided into two groups, namely typical and atypical. Typical symptoms are the most frequently reported clinical manifestations. The virus enters through the nose and mouth and attacks the respiratory tract with typical symptoms, namely fever $>38^{\circ} \mathrm{C}$ and $\operatorname{cough}^{12}$. Conversely, atypical symptoms are clinical manifestations originating from organs other than the lungs. The reactive results from patients examined by the rapid test showed that $42.9 \%$ were asymptomatic or lacked available data. In comparison, $57.1 \%$ were symptomatic, with typical symptoms such as fever, cough, respiratory syndrome, sore throat, pneumonia, loss of taste and smell, and atypical symptoms including malaise, nausea, gastrointestinal disorders, headaches, and fatigue, as shown in Table 4.

The rapid test is verified through a diagnostic test to confirm the patients' status, whether positive or negative. Real-time polymerase chain reaction (RT-PCR) testing of SARS-CoV-2 


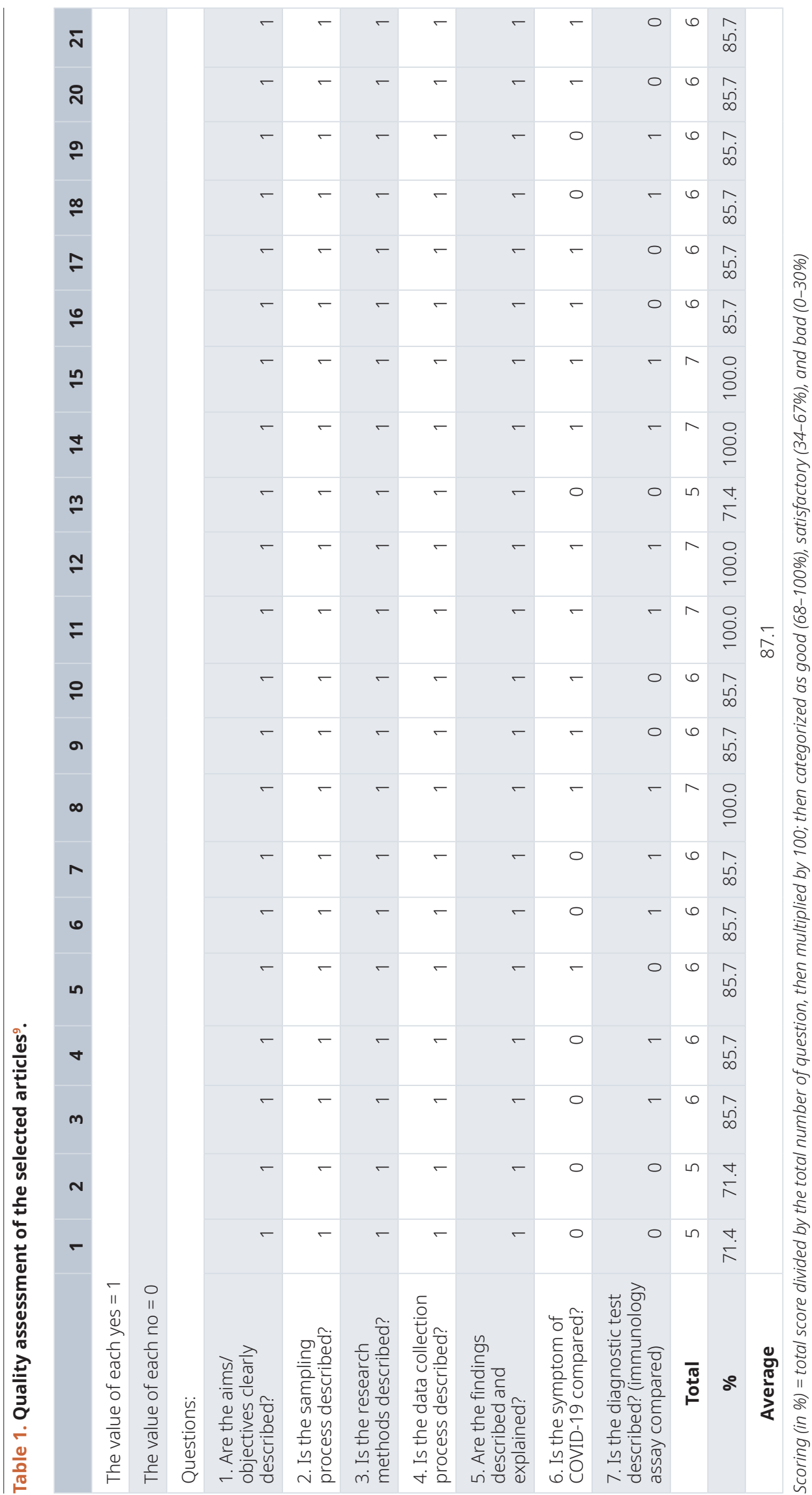




\section{Appendix}

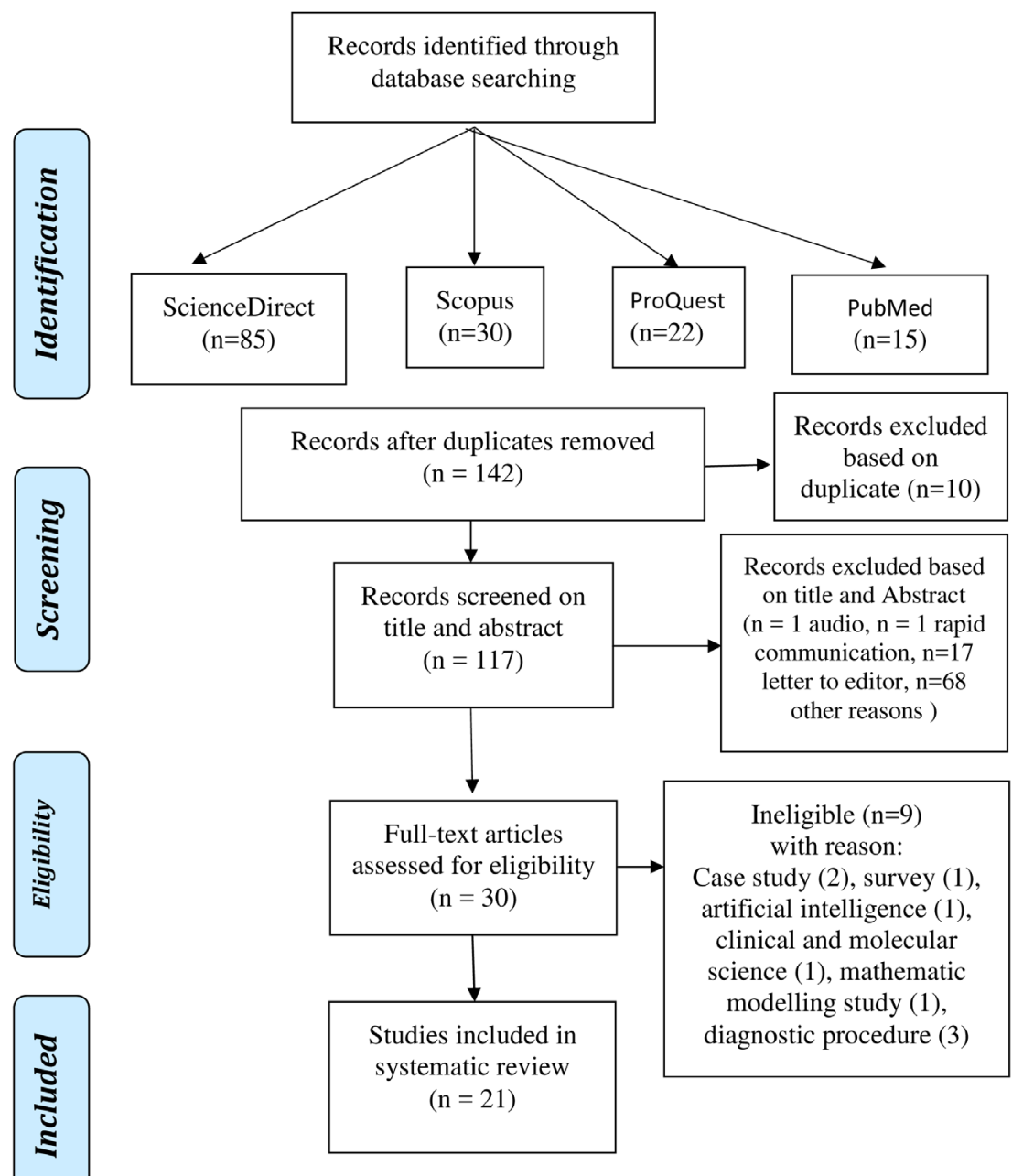

Figure 1. Flow chart of the search strategy and article selection.

has become a standard method for direct diagnosis. Currently, RT-PCR is used to diagnose COVID-19 by detecting genetic material of the coronavirus ${ }^{13}$. Serologic and immunological tests such as ELISA (enzyme linked immunosorbent assay), POC or LFA (point-of-care lateral flow assay), and CLIA (chemiluminescence immunoassay) complement RT-PCR examinations in screening and diagnosis of COVID-19.

Meanwhile, the POC or LFA is a type of rapid examination for diagnosing infectious diseases and the results are shown within minutes, permitting quick decisions regarding the patients' care. POC also extends its testing to communities and populations that do not have easy access to health care $^{14}$. ELISA is an analytical biochemical test that is used to evaluate the presence of an antigen or antibody in a sample. It is useful in the determination of serum antibody concentration ${ }^{15}$. CLIA is the assay for detection antibodies against the SARS-CoV-2 nucleoprotein $(\mathrm{Np})$ in serum or plasma.
Only 11 articles out of 21 titles provided sensitivity or specificity data (Table 5a and Table 5b). At 14 days after symptom onset, the test results were in $\operatorname{IgG}, \operatorname{IgM}$, and $\operatorname{IgA}$ (antibody) values, because at that particular time-point, antibodies have formed. Immunoglobin $\mathrm{M}$ ( $\operatorname{IgM}$ ) tends to increase within 3-14 days after infection and is replaced by Immunoglobin $\mathrm{G}$ (IgG) for 7 to 15 days, which tends to remain detectable for months. Meanwhile, immunoglobin A ( $\operatorname{Ig} \mathrm{A})$ is usually used to diagnose disorders in the immune system and detect mucosal secretions such as saliva. The sensitivity indicates the ability of the test to show a positive result. Therefore, the higher the test sensitivity, the greater the positive test results, and the lesser the number of false negatives.

Specificity indicates a test's ability to show a negative result for individuals who do not have the virus. Therefore, the higher it is, the more negative test results, or the fewer false positives $^{16}$. Overall, the sensitivity and specificity tend to be 


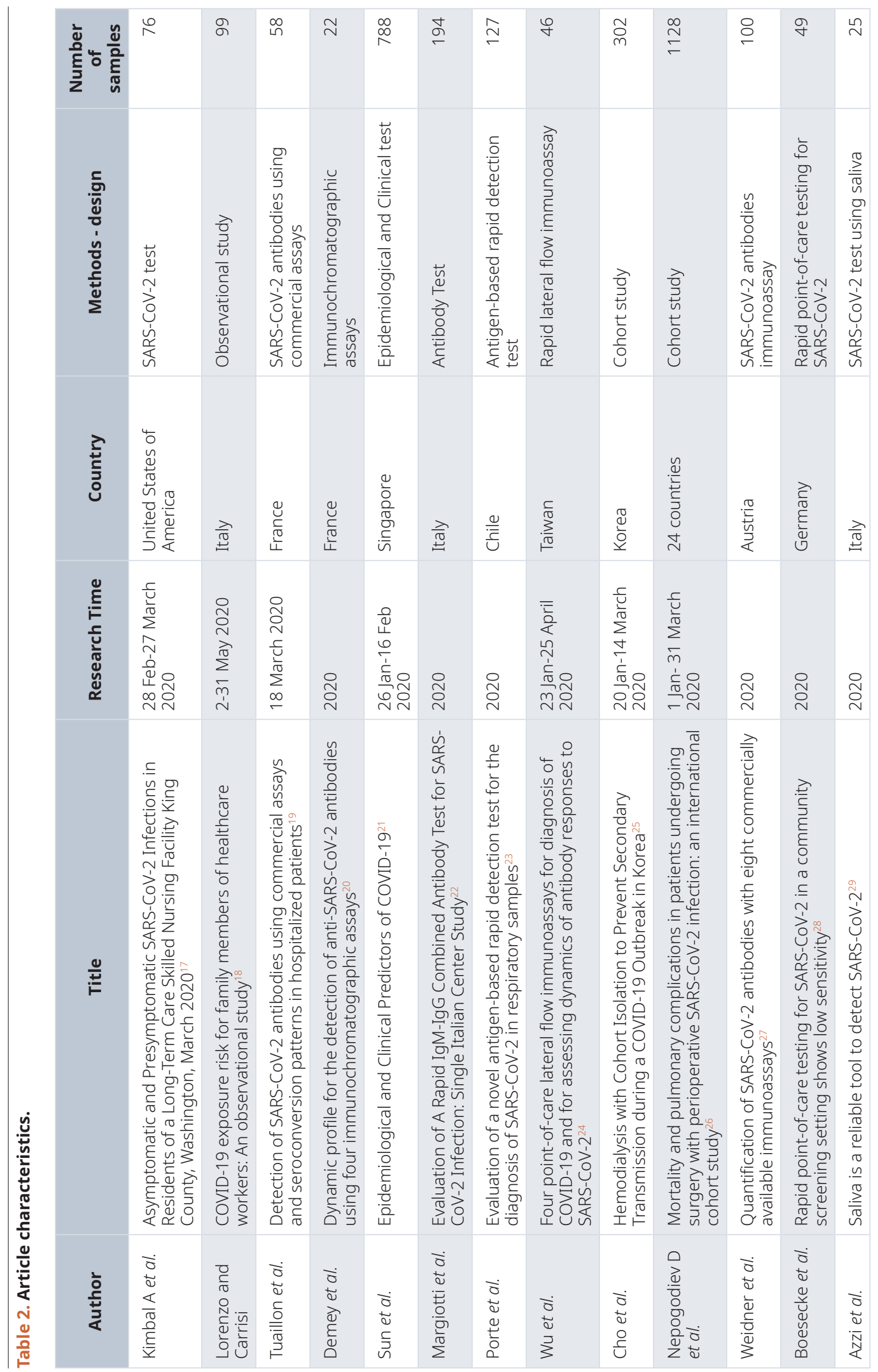




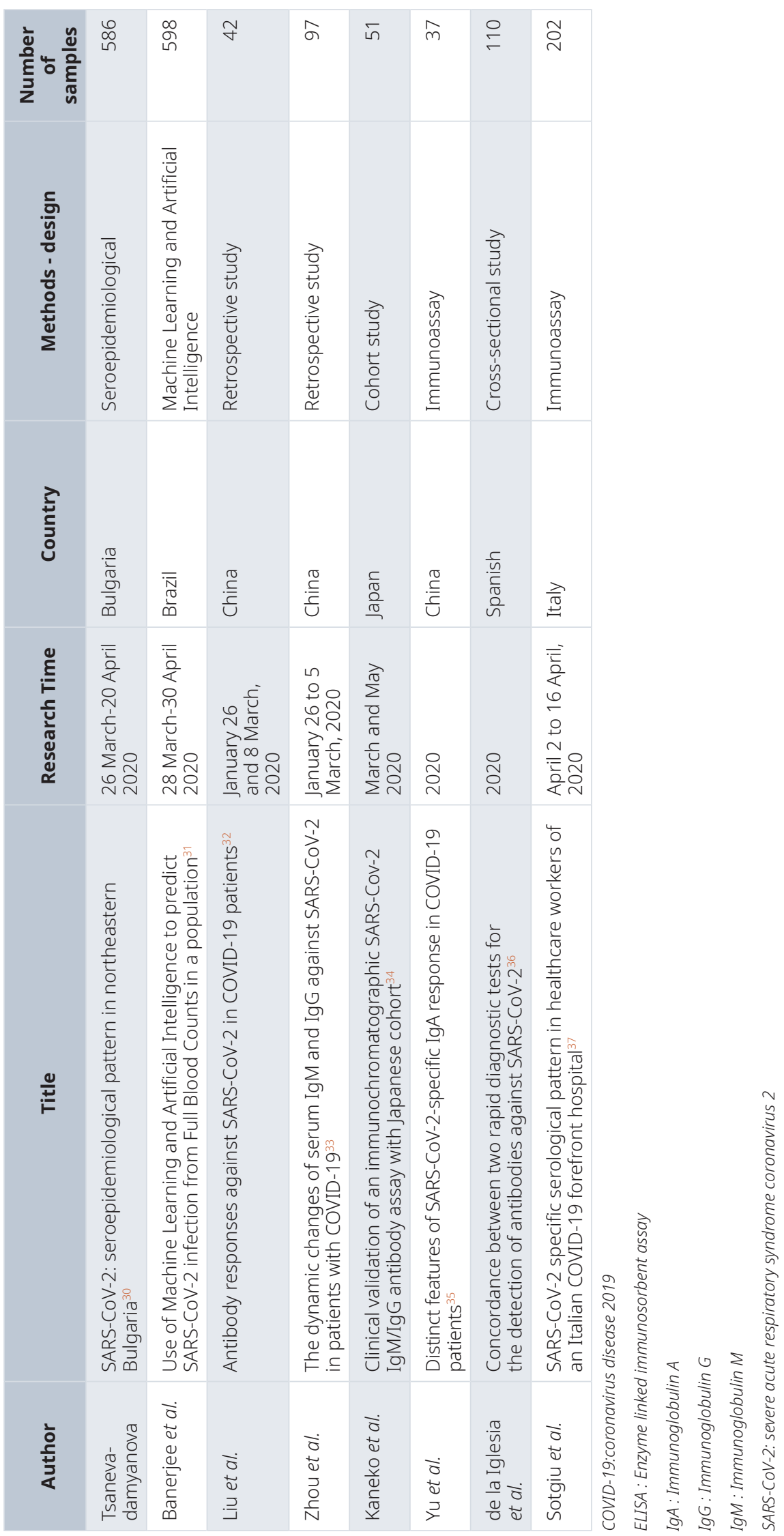


Table 3. Screening tests used to detect COVID-19.

\begin{tabular}{|c|c|c|c|c|c|c|c|c|c|c|}
\hline \multirow{2}{*}{ No } & \multirow{2}{*}{ Author } & \multicolumn{3}{|c|}{ Rapid antigen test (swab) } & \multicolumn{3}{|c|}{$\begin{array}{c}\text { Rapid antibody test (blood- } \\
\text { serum/plasma) }\end{array}$} & \multirow{2}{*}{$\begin{array}{l}\text { Average Age } \\
\text { (years) }\end{array}$} & \multicolumn{2}{|c|}{ Gender (\%) } \\
\hline & & $\mathbf{n}$ & $\begin{array}{l}\text { Positive } \\
\text { (n) }\end{array}$ & $\begin{array}{l}\text { Positive } \\
\text { (\%) }\end{array}$ & $\mathrm{n}$ & $\begin{array}{l}\text { Positive } \\
\text { (n) }\end{array}$ & $\begin{array}{l}\text { Positive } \\
\text { (\%) }\end{array}$ & & Male & Female \\
\hline 1 & Kimball A et al. & 76 & 23 & 30.3 & - & - & - & 80.7 & 0 & 100 \\
\hline 2 & Sun et al. & 788 & 54 & 6.9 & - & - & - & 42 & 53.7 & 46.3 \\
\hline 3 & Porte et al. & 127 & 82 & 64.6 & - & - & - & 38 & 53.7 & 46.3 \\
\hline 4 & Cho et al. & 302 & 18 & 6.0 & - & - & - & 55.5 & 44.4 & 55.6 \\
\hline 5 & Nepogodiev D et al. & 1128 & 1128 & 100.0 & - & - & - & 70 & 52.8 & 47.2 \\
\hline 6 & Azzi et al. & 25 & 25 & 100.0 & - & - & - & 61.5 & 68 & 32 \\
\hline 7 & Liu et al. & 42 & 42 & 100.0 & - & - & - & 61 & 33.3 & 66.7 \\
\hline 8 & Sotgiu et al. & 202 & 7 & 3.5 & - & - & - & 45 & 34.7 & 65.3 \\
\hline 9 & Lorenzo and Carrisi & - & - & - & 99 & 28 & 28.3 & 47 & NA & NA \\
\hline 10 & Tuaillon et al. & - & - & - & 58 & 38 & 65.5 & $65-72$ & 57.8 & 42.2 \\
\hline 11 & Demey et al. & - & - & - & 22 & 22 & 100.0 & NA & NA & NA \\
\hline 12 & Margiotti et al. & - & - & - & 194 & 132 & 68.0 & 35.5 & 42.4 & 57.6 \\
\hline 13 & Wu et al. & - & - & - & 46 & 16 & 34.8 & 45.6 & 56.3 & 43.7 \\
\hline 14 & Weidner et al. & - & - & - & 100 & 98 & 98.0 & 47 & 61 & 39 \\
\hline 15 & Boesecke et al. & - & - & - & 49 & 22 & 44.9 & 46 & 51 & 49 \\
\hline 16 & Tsaneva-damyanova & - & - & - & 586 & 28 & 4.8 & 45 & 35.7 & 64.3 \\
\hline 17 & Banerjee et al. & - & - & - & 598 & 81 & 13.5 & NA & NA & NA \\
\hline 18 & Zhou et al. & - & - & - & 97 & 97 & 100.0 & 65 & NA & NA \\
\hline 19 & Kaneko et al. & - & - & - & 51 & 51 & 100.0 & 63 & 72.5 & 27.5 \\
\hline 20 & Yu et al. & - & - & - & 37 & 37 & 100.0 & 52 & 67.6 & 32.4 \\
\hline 21 & de la Iglesia et al. & - & - & - & 110 & 58 & 52.7 & 48 & 48 & 52 \\
\hline \multicolumn{2}{|l|}{ Total } & 2690 & 1379 & 51.3 & 2047 & 708 & 34.6 & & & \\
\hline
\end{tabular}

Legend: NA= Not Available

accurate or have high values after 14 days of onset with 100 for all immunoassay assays, as shown in Table 5a and Table 5b.

\section{Discussion}

High-risk group

Indonesia's government implemented a Rapid Test policy to accelerate the early detection of confirmed cases, both among health workers and other high-risk groups. However, this test has drawbacks because positive results are only obtainable among individuals with COVID-19 antibodies in their blood, which are generally formed on the seventh day after infection. Consequently, there is a possibility of the result being negative but does not mean that the individual is not infected. This occurrence is since the antibodies are yet to be formed; therefore, repetition is needed. The implementation of the rapid test is intended for individuals that are at risk. However, in this current condition, mass testing could be carried out considering the number of infected people without symptoms that have not received treatment and monitoring, which are all sources of transmission.

The elderly and individuals with pre-existing medical conditions such as high blood pressure, heart and lung disorders, diabetes, and cancer are at greater risk of experiencing severe COVID-19 symptoms $^{38}$. Furthermore, travelers and individuals who have had close contact with infected individuals and medical personnel ${ }^{39}$. Therefore, surveillance for this group needs to be carried out daily with active case finding through screening for signs and symptoms and checking body temperature ${ }^{39}$. Based on gender distribution, males are presumed to be 


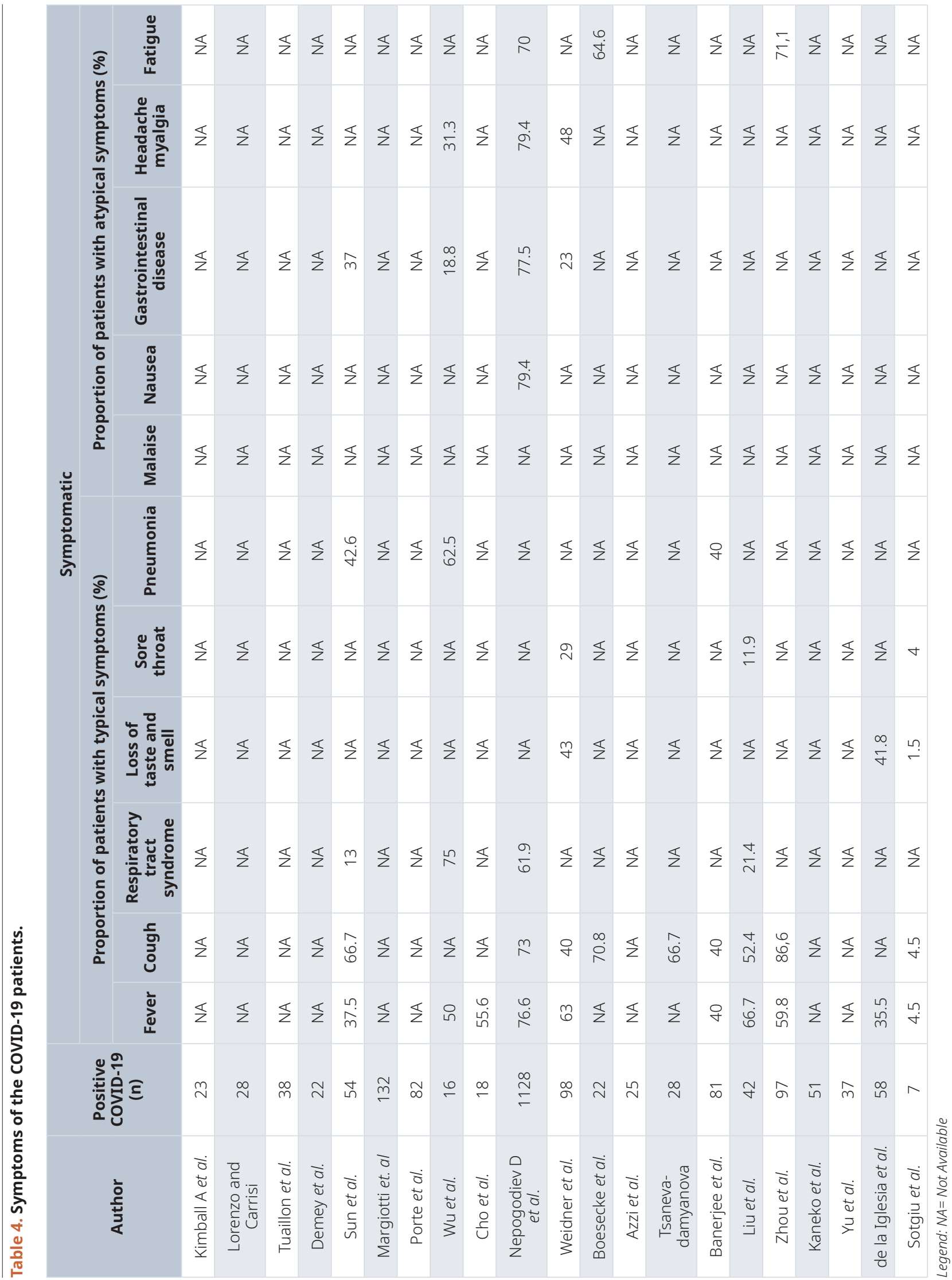


Table 5a. Sensitivity and specificity of diagnostic tests used in the reviewed articles.

\begin{tabular}{|c|c|c|c|c|c|c|c|c|}
\hline \multirow[b]{2}{*}{ Author } & \multicolumn{4}{|c|}{$\leq 14$ days after onset $(\%)$} & \multicolumn{4}{|c|}{$>14$ days after onset (\%) } \\
\hline & RT PCR & ELISA & POC LFA & CLIA & $\begin{array}{l}\text { RT } \\
\text { PCR }\end{array}$ & ELISA & POC LFA & CLIA \\
\hline \multirow[t]{2}{*}{ Porte et al. } & se: $80-94,7$ & & & & & & & \\
\hline & sp:100 & & & & & & & \\
\hline \multirow{4}{*}{$\begin{array}{l}\text { Tuaillon } \\
\text { et al. }\end{array}$} & & se:43-86(IgA) & se:36-93(IgG) & & & se:80-100(IgA) & se:80-100(IgG) & \\
\hline & & se:36-93 (IgG) & se:36-86 (IgM) & & & sp:80 (IgA) & sp:95-100 (IgG) & \\
\hline & & & & & & se:73-100 (IgG) & se:73-100 (IgM) & \\
\hline & & & & & & sp:85-100 (IgG) & sp:65-100(IgM) & \\
\hline \multirow[t]{2}{*}{ Kaneko et al. } & & se:81,6 (IgG) & & & & & & \\
\hline & & se:71 (IgM) & & & & & & \\
\hline \multirow[t]{2}{*}{ Demey et al. } & & & $\begin{array}{l}\text { se:9,09-100 } \\
\text { (IgG) }\end{array}$ & & & & $\begin{array}{c}\text { se:81,82-100 } \\
\text { (IgG) }\end{array}$ & \\
\hline & & & $\begin{array}{l}\text { se:4,55-100 } \\
\text { (IgM) }\end{array}$ & & & & se:100 (IgM) & \\
\hline \multirow[t]{2}{*}{ Wu et al } & & & $\begin{array}{c}\text { se: } 41,3-52,2 \\
\text { (NA) }\end{array}$ & & & & se:87-100(NA) & \\
\hline & & & sp:100 (NA) & & & & sp:100 (NA) & \\
\hline \multirow[t]{3}{*}{ Yu et al. } & & & & se: $98,9(\operatorname{Ig} A)$ & & & & se: $100(\operatorname{Ig} A)$ \\
\hline & & & & se:95,1 (IgG) & & & & se:100 (IgG) \\
\hline & & & & se:93,4(IgM) & & & & se:100 (IgM) \\
\hline
\end{tabular}

Table 5b. Sensitivity and specificity of diagnostic tests used in the reviewed articles.

\begin{tabular}{|c|c|c|c|c|}
\hline \multirow[t]{2}{*}{ Author } & \multicolumn{4}{|c|}{ Not Available days after onset } \\
\hline & RT PCR & ELISA & POC LFA & CLIA \\
\hline \multirow[t]{2}{*}{ Margioti et al. } & se:95,5(NA) & & & \\
\hline & sp:96,8(NA) & & & \\
\hline \multirow[t]{2}{*}{ Boesecke et al. } & se:36,4(NA) & & & \\
\hline & sp:88,9(NA) & & & \\
\hline \multirow[t]{2}{*}{ Banerjee et al. } & se:43-92(NA) & & & \\
\hline & sp:58-94(NA) & & & \\
\hline Weidner et al. & & se:88,89-98(NA) & se:88.78-92,93(NA) & se:84,94-95(NA) \\
\hline \multirow[t]{4}{*}{ Tsaneva damyanova } & & & se:100(IgG) & \\
\hline & & & sp:98(IgG) & \\
\hline & & & se:85(IgM) & \\
\hline & & & sp:96(IgM) & \\
\hline \multicolumn{5}{|l|}{ Se: sensitivity } \\
\hline \multicolumn{5}{|l|}{ Sp: specificity } \\
\hline \multicolumn{5}{|c|}{ RT-PCR : Real time-polymerase chain reaction } \\
\hline \multicolumn{5}{|c|}{ ELISA: Enzyme-linked immunosorbent assay } \\
\hline \multicolumn{5}{|c|}{ POC LFA: Point-of-care lateral flow assay } \\
\hline \multicolumn{5}{|c|}{ CLIA: Chemiluminescence immunoassay } \\
\hline$N A=$ Not available & & & & \\
\hline
\end{tabular}


associated with a higher prevalence of active smoking ${ }^{40}$. It is suspected that there is an increase in ACE2 receptor expression in smokers, people with hypertension, and diabetes mellitus $^{40,41}$.

\section{Case findings}

The COVID-19 pandemic has been driven by crossborder human mobility and region-specific COVID-19 susceptibilityy ${ }^{42}$. The diagnosis of new cases is inseparable from early precautions ${ }^{2}$. One method of how a diagnosis is carried out is via screening. During the COVID-19 pandemic, screening at airports has been a priority due to its spread in 113 countries globally, which allegedly started in Wuhan (China). Initially, it was only a thermal test developed into a quarantine system at airports or ports. While active screening at airports is still an effective method for detecting new diseases, it does not provide $100 \%$ efficacy in case detection ${ }^{43}$ because there are passive cases that are yet reported at health services.

Surveillance activities may be either passive or active. In passive surveillance, the health department passively receives reports of suspected injury or illness. Conversely, epidemiologists actively seek out cases of disease ${ }^{44}$. The detection of passive cases is triggered by patients seeking to be treated by doctors working in health facilities. Meanwhile, active screening detects $80 \%$ and $20 \%$ of imported and passive cases, respectively ${ }^{43}$.

The active case findings under rapid tests in the community, for instance, in Indonesia, are currently being carried out by inviting individuals to various designated places, such as the health office, stadium, village centers, markets, and schools. South Korea adopted a test kit from SD Biosensor to carry out mass testing in its country as a preventive. This test has proven to be a practical rapid screening step, consequently reducing the death rate. However, this rapid test is also supported by the PCR test with free drive-through service. The test kit's performance is influenced by several factors, such as the period of emergence of symptoms, the concentration of virus in the specimen, quality and method of processing, and the reagent formulation in test $\mathrm{kit}^{45}$.

\section{Symptoms of COVID-19 patients}

The terms for COVID-19 patients are divided into several groups, namely patients under monitoring (ODP) or close contacts, patients under supervision (PDP) or suspected cases, and patients without symptoms (OTG) or confirmed cases without symptoms ${ }^{11}$. The clinical manifestations of COVID-19 have a broad spectrum, ranging from asymptomatic, mild symptoms, pneumonia, severe pneumonia, acute respiratory distress syndrome (ARDS), sepsis to septic shock. Approximately $80 \%$ of cases have been classified as mild or moderate, $13.8 \%$ as severe, and over $6.1 \%$ as under critical condition ${ }^{46}$. These manifestations usually appear within 2 to 14 days after exposure and common signs include acute respiratory symptoms such as fever, cough, and difficulty breathing. In severe cases, COVID-19 symptoms include pneumonia, ARDS, kidney failure, and even death. The severity of symptoms is influenced by the immune system, age, certain comorbidities such as hypertension, diabetes mellitus, asthma, heart disease, obesity, and some habits such as smoking, lack of exercise, and staying in poorly ventilated rooms ${ }^{47}$.

\section{Diagnostic test}

The incubation period from when the virus was initially contracted to manifesting the first symptoms is usually 5 to 7 days (or within the range of 4-14 days). Current infection diagnosis relies on tests to detect the virus in various bodily fluids. Previous infections are confirmed through blood tests, and negative tests presume immunity to re-infection, although the duration and effectiveness of this protection are still unknown ${ }^{48}$.

Laboratory-based molecular tests for detecting SARS-CoV-2 in the respiratory specimens are the current reference standard used to diagnose COVID-19, although serological immunoassays are rapidly being developed ${ }^{49}$. One example of detection used respiratory specimens was conducted in Independent and Assisted Living Community for Older Adults - Seattle, Washington $^{42}$. The detection of SARS-CoV-2 using nasopharyngeal swabs was carried out twice, precisely day-one and seven, on the staff members. The positive cases in the first round were isolated immediately using personal protective equipment irrespective of whether they showed no symptoms. Furthermore, in the second round, positive cases were also discovered among the people who did not have symptoms initially. This analysis needs to be carried out because positive cases are bound to be found in the housing of a group of elderly or nursing homes. Therefore, this examination need not be carried out only once ${ }^{42}$. IgM detection and $\operatorname{IgA}$ detection were possible from days 3 to 6 after the onset of the symptoms, while IgG starts to emerge from days 10 to $18^{50}$. Consequently, rapid antibody test is not recommended by the World Health Organization (WHO) as the primary basis for diagnosis. Therefore, serologically negative patients still need to be observed and re-examined to be confirmed ${ }^{51}$.

\section{Strengths and weaknesses of this study}

This study reported that all COVID-19 tests are effective when carried out in accordance with their purpose and objectives. However, not all studies reviewed have a similar pattern. Therefore only a few were compared. Meanwhile, the cost of rapid testing was not discussed, which varies widely and allows for differences in the examinations' quality.

\section{Conclusion}

The elderly and individuals with pre-existing medical conditions such as high blood pressure, heart and lung disorders, diabetes, and cancer are at greater risk of experiencing severe COVID-19 symptoms. Finding new COVID-19 cases during this pandemic situation is extremely necessary to aid early detection with proper and mass surveillance. Therefore, treatments can be quickly administered and the source of transmission reduced. Tests for COVID-19 are generally divided into two, namely targeting the virus RNA and protein. The PCR method is targeted for RNA, while rapid tests for antigens and antibodies are targeted for proteins. The accuracy of these tests is supported by the sampling method from the incubation, emergence of symptoms, and healing period. Furthermore, the exposed individuals' contact history or positive case is 
also a significant factor determining sampling time with the appropriate type of test. The WHO recommends a rapid antigen test as an alternative supposing PCR is not available, therefore interfering with the handling of COVID-19 patients and the pandemic response process ${ }^{52}$. Meanwhile, the rapid antigen test is effective when the number of cases is high because it detects virus material directly after symptoms. The result is known faster than the PCR test, compared to the rapid antibody test that increases in the second and third weeks after the onset of symptoms. Therefore, the order starts from the PCR test, then supposing it is unavailable, the rapid antigen test serves as an alternative when compared with the antibody test. However, the diagnosis should be confirmed using the PCR. Based on this study, the accuracy of most diagnostic tests such as RT-PCR, ELISA, POC LFA, CLIA, CEFA, and MIA sensitivity and specificity is increased in the late phase (> 14 days) after the onset of symptoms. This accuracy is helpful in the identification of individuals that have been exposed to COVID-19. To achieve an early diagnosis of COVID-19, according to disease progression, gradual rapid tests can be used, such as rapid antigen in an earlier week and antibody tests confirmed by RT-PCR and serological assay in the second week of COVID-19.

\section{Data availability}

Underlying data

All data underlying the results are available as part of the article and no additional source data are required.

\section{Reporting guidelines}

Figshare: PRISMA checklist for 'A systematic review on the case findings and management of COVID-19; in the link https://doi. org/10.6084/m9.figshare.13586081.v $1^{8}$

Data are available under the terms of the Creative Commons Attribution 4.0 International license (CC-BY 4.0).

\section{Acknowledgments}

The authors would like to thank to the Directorate of Research and Development Universitas Indonesia for supporting the financial through Grant No NKB-2605/UN2.RST/HKP.05.00/2020. The authors also gratefully acknowledge the Library of Universitas Indonesia for providing the databases used in this review.
1. Lim J, Jeon S, Shin HY, et al:: Case of the index patient who caused tertiary transmission of coronavirus disease 2019 in Korea: The application of lopinavir/ritonavir for the treatment of COVID-19 pneumonia monitored by quantitative RT-PCR. J Korean Med Sci. 2020; 35(6): e79. PubMed Abstract | Publisher Full Text | Free Full Text

2. Kemenkes RI: PEDOMAN PENCEGAHAN DAN PENGENDALIAN CORONAVIRUS DISESASE (COVID-19). 2020; 1-214. Reference Source

3. $\mathrm{Xu} \mathrm{TL}$, Ao MY, Zhou X, et al:: China's practice to prevent and control Covid-19 in the context of large population movement. Infect Dis Poverty. 2020; 9(1): 115.

PubMed Abstract | Publisher Full Text | Free Full Text

4. El-Taliawi OG, Hartley K: The COVID-19 crisis and complexity: A soft systems approach. J Contingencies Cris Manag. 2020; 1468-5973.12337. Publisher Full Text

5. Shariare MH, Parvez MAK, Karikas GA, et al:: The growing complexity of COVID-19 drug and vaccine candidates: challenges and critical transitions. Infect Public Health. 2020; 14(2): 214-220.

PubMed Abstract | Publisher Full Text | Free Full Text

6. Bratianu C: Toward understanding the complexity of the COVID-19 crisis: A grounded theory approach. Manag Mark. 2020; 15(s1): 410-423. Publisher Full Text

7. Li X, Geng M, Peng Y, et al:: Molecular immune pathogenesis and diagnosis of COVID-19. J Pharm Anal. 2020; 10(2): 102-108.

PubMed Abstract | Publisher Full Text | Free Full Text

8. Susanna D: A systematic review on the case findings and management of COVID-19. figshare. Dataset. 2021.

http://www.doi.org/10.6084/m9.figshare.13586081.v1

9. Schenck R, Blaauw D, Viljoen K: Enabling factors for the existence of waste pickers: A systematic review. Soc Work (South Africa). 2016; 52(1): 35-53. Publisher Full Text

10. Yetisen AK, Akram MS, Lowe CR: Paper-based microfluidic point-of-care diagnostic devices. Lab Chip. 2013; 13(12): 2210-2251. PubMed Abstract | Publisher Full Text

11. BNPB: Gugus tugas percepatan penanganan covid-19. 2020; 1-39. Reference Source

12. WHO: WHO COVID-19: Case Definitions. 2020; 2020. Reference Source
13. Jawerth N: How is the COVID-19 Virus Detected using Real Time RT-PCR? 2020; $1-6$. Reference Source

14. CDC: Symptoms of Coronavirus ( COVID-19). 2020; 316475. Reference Source

15. Medline: Screening and diagnosis for HIV How the Test is Performed. 2020; 11-14. Reference Source

16. Gede IW, Eka A, Epid M, et al.: UJI DIAGNOSTIK DAN SKRINING. 2016.

17. Kimball A, Hatfield KM, Arons $M$, et al.: Asymptomatic and Presymptomatic SARS-CoV-2 Infections in Residents of a Long-Term Care Skilled Nursing Facility - King County, Washington, March 2020. MMWR Morb Mortal Wkly Rep. 2020; 69(13): 377-381.

PubMed Abstract | Publisher Full Text | Free Full Text

18. Lorenzo D, Carrisi C: COVID-19 exposure risk for family members of healthcare workers: An observational study. Int J Infect Dis. 2020; 98: 287-289.

PubMed Abstract | Publisher Full Text | Free Full Text

19. Tuaillon E, Bolloré K, Pisoni A, et al.: Detection of SARS-CoV-2 antibodies using commercial assays and seroconversion patterns in hospitalized patients. J Infect. 2020; 81(2): e39-e45.

PubMed Abstract | Publisher Full Text | Free Full Text

20. Demey B, Daher N, François C, et al.: Dynamic profile for the detection of anti-SARS-CoV-2 antibodies using four immunochromatographic assays. J Infect. 2020; 81(2): e6-e10.

PubMed Abstract | Publisher Full Text | Free Full Text

21. Sun $Y$, Koh V, Marimuthu K, et al.: Epidemiological and Clinical Predictors of CoviD-19. Clin Infect Dis. 2020; 71(15): 786-792.

PubMed Abstract | Publisher Full Text | Free Full Text

22. Margiotti K, Cupellaro M, Emili S, et al.: Evaluation of A Rapid IgM-IgG Combined Antibody Test for SARS-CoV-2 Infection : Single Italian Center Study. Am J Infect Dis. 2020; 16(2): 85-88.

Publisher Full Text

23. Porte L, Legarraga $P$, Vollrath V, et al.: Evaluation of a novel antigen-based rapid detection test for the diagnosis of SARS-CoV-2 in respiratory samples. Int J Infect Dis. 2020; 99: 328-333. PubMed Abstract | Publisher Full Text | Free Full Text

24. Wu JL, Tseng WP, Lin CH, et al.: Four point-of-care lateral flow immunoassays 
for diagnosis of COVID-19 and for assessing dynamics of antibody responses to SARS-CoV-2. J Infect. 2020; 81(3): 435-442. PubMed Abstract | Publisher Full Text | Free Full Text

25. Cho J, Kang SH, Park HC, et al.: Hemodialysis with Cohort Isolation to Prevent Secondary Transmission during a COVID-19 Outbreak in Korea. J Am Soc Nephrol. 2020; 31(7): 1398-1408.

PubMed Abstract | Publisher Full Text | Free Full Text

26. Nepogodiev D, Bhangu A, Glasbey JC, et al.: Mortality and pulmonary complications in patients undergoing surgery with perioperative SARSCoV-2 infection: an international cohort study. Lancet. 2020; 396(10243): 27-38.

PubMed Abstract | Publisher Full Text | Free Full Text

27. Weidner L, Gänsdorfer S, Unterweger S, et al.: Quantification of SARS-CoV-2 antibodies with eight commercially available immunoassays.J Clin Virol. 2020; 129: 104540

PubMed Abstract | Publisher Full Text | Free Full Text

28. Döhla M, Boesecke C, Schulte B, et al.: Rapid point-of-care testing for SARS CoV-2 in a community screening setting shows low sensitivity. Public Health. 2020; 182: 170-172.

PubMed Abstract | Publisher Full Text | Free Full Text

29. Azzi L, Carcano G, Gianfagna F, et al.: Saliva is a reliable tool to detect SARS-CoV-2. J Infect. 2020; 81(1): e45-e50.

PubMed Abstract | Publisher Full Text | Free Full Text

30. Tsaneva-damyanova D: SARS-CoV-2 : seroepidemiological pattern in northeastern Bulgaria. Biotechnol Biotechnol Equip. 2020; 34(1): 441-446. Publisher Full Text

31. Banerjee A, Ray S, Vorselaars B, et al.: Use of Machine Learning and Artificia Intelligence to predict SARS-CoV-2 infection from Full Blood Counts in a population. Int Immunopharmacol. 2020; 86: 106705.

PubMed Abstract | Publisher Full Text | Free Full Text

32. Liu A, Li Y, Huang Y, et al:: Antibody responses against SARS-CoV-2 in COVID-19 patients. J Med Virol. 2020; 93(1): 144-148.

PubMed Abstract | Publisher Full Text | Free Full Text

33. Zhou $\mathrm{W}, \mathrm{Xu} X$, Chang $\mathrm{Z}$, et al.: The dynamic changes of serum IgM and IgG against SARS-CoV-2 in patients with COVID-19. J Med Virol. 2020; 93(2): 924-933.

PubMed Abstract | Publisher Full Text | Free Full Text

34. Kaneko S: Clinical validation of an immunochromatographic SARS-Cov-2 IgM IgG antibody assay with Japanese cohort. J Med Virol. 2021; 93(1): 569-572. PubMed Abstract | Publisher Full Text

35. Yu H, Sun B, Fang Z, et al.: Distinct features of SARS-CoV-2-specific IgA response in COVID-19 patients. Eur Respir J. 2020; 56(2): 2001526. PubMed Abstract | Publisher Full Text | Free Full Text

36. de la Iglesia J, Fernández-Villa T, Fegeneda-Grandes JM, et al.: Concordance between two rapid diagnostic tests for the detection of antibodies against SARS-CoV-2. Semergen. 2020; 46 Suppl 1: 21-25.

PubMed Abstract | Publisher Full Text | Free Full Text

37. Sotgiu G, Barassi A, Miozzo M, et al.: SARS-CoV-2 specific serological pattern in healthcare workers of an Italian COVID-19 forefront hospital. BMC Pulm Med. 2020; 20(1): 203

PubMed Abstract | Publisher Full Text | Free Full Text

38. WHO: COVID-19: vulnerable and high risk groups. 2020; 1-6.
39. Kementerian Kesehatan Republik Indonesia: PEDOMAN PENCEGAHAN DAN PENGENDALIAN CORONAVIRUS DISESASE (COVID-19). REV-5. (Aziza Listiana; Aqmarina Adistiqah; Insan Maulidiah, ed.). Jakarta: Kementerian Kesehatan RI 2020; Accessed January 8, 2021 Reference Source

40. Cai H: Sex difference and smoking predisposition in patients with COVID-19. Lancet Respir Med. 2020; 8(4): e20. PubMed Abstract | Publisher Full Text | Free Full Text

41. Fang L, Karakiulakis G, Roth M: Are patients with hypertension and diabetes mellitus at increased risk for COVID-19 infection? Lancet Respir Med. 2020; 8(4): e21.

PubMed Abstract | Publisher Full Text | Free Full Text

42. Roxby AC, Greninger AL, Hatfield KM, et al.: Detection of SARS-CoV-2 Among Residents and Staff Members of an Independent and Assisted Living Community for Older Adults - Seattle, Washington, 2020. MMWR Morb Mortal Wkly Rep. 2020; 69(14): 416-418.

PubMed Abstract | Publisher Full Text | Free Full Text

43. Sookaromdee P, Wiwanitkit V: Imported Novel Coronavirus Infections: Observation on Active and Passive Case Detection in Thailand. Popul Health Manag. 2021; 24(1): 149 PubMed Abstract | Publisher Full Text

44. Jamison DT, Breman JG, Measham AR, et al.: Disease Control Priorities in Developing Countries 2nd Edition. Second edi. Washington DC: The International Bank for Reconstruction and Development / The World Bank; 2006; Accessed December 28, 2020. Reference Source

45. World Health Organization: Manual for the Laboratory Diagnosis and Virological Surveillance of Influenza. Malta; 2011. Reference Source

46. WHO: Report of the WHO-China Joint Mission on Coronavirus Disease 2019 ( COVID-19) 2020; 2019: 16-24. Reference Source

47. Nadia: KESIAPAN KEMENKES DALAM MENGHADAPI OUTBREAK NOVEL CORONAVIRUS ( 2019-nCoV ). 2020.

48. Beeching NJ, Fletcher TE, Beadsworth MBJ: Covid-19: testing times. Rapid near patient testing for both current and past infections is urgently required. $B M$ J. 2020; 369: m1403.

PubMed Abstract | Publisher Full Text

49. Cheng MP, Papenburg J, Desjardins M, et al.: Diagnostic Testing for Severe Acute Respiratory Syndrome-Related Coronavirus 2: A Narrative Review. Ann Intern Med. 2020; 172(11): 726-734. PubMed Abstract | Publisher Full Text | Free Full Text

50. Guo L, Ren L, Yang S, et al:: Profiling Early Humoral Response to Diagnose Novel Coronavirus Disease (COVID-19). Clin Infect Dis. 2020; 71(15): 778-785. PubMed Abstract | Publisher Full Text | Free Full Text

51. WHO: Laboratory testing for coronavirus disease 2019 ( COVID-19) in suspected human cases. 2020; 2019 Reference Source

52. WHO (World Health Organization): Saran Penggunaan Tes Imunodiagnostik Di Fasyankes ( Point of Care ) Untuk COVID-19. 2020 Reference Source 


\section{Open Peer Review}

\section{Current Peer Review Status: ?}

\section{Version 1}

Reviewer Report 04 October 2021

https://doi.org/10.5256/f1000research.54024.r94254

(C) 2021 Bhaskar S. This is an open access peer review report distributed under the terms of the Creative Commons Attribution License, which permits unrestricted use, distribution, and reproduction in any medium, provided the original work is properly cited.

\section{Sonu Menachem Maimonides Bhaskar}

1 Liverpool Hospital, Liverpool, NSW, Australia

2 Ingham Institute, Liverpool, NSW, Australia

3 Global Health Neurology Lab and NSW Brain Clot Bank, Sydney, NSW, Australia

This is an interesting review of the case findings, testing, and management of COVID-19. The article needs substantial revision for its content. Here are some general comments for the authors to consider:

1. In the Abstract, the authors state "This review aimed to examine the outcome of the existing studies on the ways of identifying COVID-19 cases...", please revise this to "..examine the variations in COVID-19 diagnostic testing and clinical characteristics across various studies.". The study doesn't provide data on management protocols or on the outcomes.

2. The Discussion lacks a concrete summary. Please summarise the findings relevant to this systematic review.

3. Table 1 should be provided as a part of the Results.

4. In Table 2, the data on clinical characteristics, such as risk factors, COVID-19 severity, etc., are not provided and could be included. Moreover, please change the legend of Table 2 to "Clinical and demographic characteristics of studies included in the systematic review".

5. In the Discussion, "High-risk group" section, the authors make statements that are not appropriately referenced and lacks context from the standpoint of the overall findings of this review.

6. The authors discuss the symptoms in Table 4; however, several studies have not reported on various symptoms or data is simply not available?

7. The authors conclude "The elderly and individuals with pre-existing medical conditions such 
as high blood pressure, heart and lung disorders, diabetes, and cancer are at greater risk of experiencing severe COVID-19 symptoms.". But this is not supported by the findings of this study. The authors didn't examine these associations in this systematic review.

8. The Conclusion and Discussion need substantial revision focussing on the findings of this systematic review only. The accuracy of rapid antigen tests remains debatable, therefore, unless not available, RT-PCR should be preferred as the first-line strategy.

9. The authors need to expand upon the statistical analysis, as in what descriptive statistics were used for subgroup analyses.

Are the rationale for, and objectives of, the Systematic Review clearly stated? Yes

Are sufficient details of the methods and analysis provided to allow replication by others? Partly

Is the statistical analysis and its interpretation appropriate?

Partly

Are the conclusions drawn adequately supported by the results presented in the review? No

Competing Interests: No competing interests were disclosed.

Reviewer Expertise: COVID-19, Public Health, Epidemiology

I confirm that I have read this submission and believe that I have an appropriate level of expertise to confirm that it is of an acceptable scientific standard, however I have significant reservations, as outlined above.

Author Response 28 Nov 2021

Dewi Susanna

Dear editor and reviewer,

Here are our responses to the reviewer comments and suggestions:

1. In the Abstract, the authors state, "This review aimed to examine the outcome of the existing studies on the ways of identifying COVID-19 cases...", please revise this to "..examine the variations in COVID-19 diagnostic testing and clinical characteristics across various studies.". The study doesn't provide data on management protocols or on the outcomes.

Author Responses:

The aim of this abstract and the last part of the introduction was revised as follows: 
The review aimed to examine the variations in COVID-19 diagnostic testing and clinical characteristics across various studies

2. The Discussion lacks a concrete summary. Please summarise the findings relevant to this systematic review.

\section{Author Responses:}

The revision of the Discussion is as follows:

a. The section High-Risk Group was changed with Commorbidies and added for the new Discussion:

\section{Comorbidities:}

COVID-19 patients with other comorbidities such as chronic obstructive pulmonary disease (COPD), cardiovascular disease (CVD), hypertension, cancer, diabetes, HIV, chronic kidney disease can cause a high risk of death. Comorbidities cause COVID-19 patients to be more at risk of increased morbidity and mortality 42-45. A cohort study in Jakarta also found a higher risk of death with comorbid patients than those without, the risk increasing sixfold among patients $<50$ years of age 46. Therefore, comorbidities can exacerbate COVID-19 infection 47.

Here are the added references, so the reference list must be reordered.

41. Ejaz $H$, Alsrhani $A$, Zafar $A$, Javed $H$, Junaid $K$, Abdalla AE, et al. COVID-19 and comorbidities: Deleterious impact on infected patients. J Infect Public Health [Internet]. 2020 Dec 1 [cited 2021 Nov 27];13(12):1833-9. Available from: https://pubmed.ncbi.nlm.nih.gov/32788073/ 42. Sanyaolu A, Okorie C, Marinkovic A, Patidar R, Younis K, Desai P, et al. Comorbidity and its Impact on Patients with COVID-19. SN Compr Clin Med. 2020;2(8):1069-76.

43 Fathi M, Vakili K, Sayehmiri F, Mohamadkhani A, Hajiesmaeili M, Rezaei-Tavirani M, et al. The prognostic value of comorbidity for the severity of COVID-19: A systematic review and meta-analysis study. PLoS One [Internet]. 2021;16(2 February):1-25. Available from: http://dx.doi.org/10.1371/journal.pone.0246190

44. Surendra H, Elyazar IR, Djaafara BA, Ekawati LL, Saraswati K, Adrian V, et al. Clinical characteristics and mortality associated with COVID-19 in Jakarta, Indonesia: A hospitalbased retrospective cohort study. Lancet Reg Heal - West Pacific [Internet]. 2021;9:100108. Available from: https://doi.org/10.1016/j.lanwpc.2021.100108 45. Klein F. Risikofaktor Komorbiditäten bei COVID-19- Erkrankung. Pneumologie. 2020;74(10):640.

b. The findings were summarised to relevant review:

The last part of the Discussion summarised the review as follows:

Various screening methods are used to detect COVID-19, such as rapid antigen and antibody tests. Early diagnosis of COVID-19 requires gradual tests such as a screening test by conducting a rapid antigen test a week earlier and an antibody test that needs to be confirmed by RT-PCR and serological tests in the second week of COVID-19. Based on this study, the accuracy of most diagnostic tests such as RT-PCR, ELISA, POC LFA, CLIA, CEFA, and MIA the sensitivity and specificity 
increased in the late phase (>14 days) after the onset of symptoms. This accuracy helps identify individuals who have been exposed to COVID-19.

3. Table 1 should be provided as a part of the Results.

\section{Author Responses:}

Table 1 moved to the results. It is put after Figure 1.

4. In Table 2, the data on clinical characteristics, such as risk factors, COVID-19 severity, etc., are not provided and could be included. Moreover, please change the legend of Table 2 to "Clinical and demographic characteristics of studies included in the systematic review".

\section{Author Responses:}

The legend of Table 2 is replaced with: "Clinical and demographic characteristics of studies included in the systematic review"

5. In the Discussion, "High-risk group" section, the authors make statements that are not appropriately referenced and lacks context from the standpoint of the overall findings of this review:

\section{Author Responses:}

The section High-Risk Group was changed with Comorbidities and the Discussion added information as shown in responses No. 2.b above.

6. The authors discuss the symptoms in Table 4; however, several studies have not reported on various symptoms or data is simply not available?

\section{Author Responses:}

The characteristics of the symptoms shown are following the results of the journals reviewed.

7. The authors conclude "The elderly and individuals with pre-existing medical conditions such as high blood pressure, heart and lung disorders, diabetes, and cancer are at greater risk of experiencing severe COVID-19 symptoms.". But this is not supported by the findings of this study. The authors didn't examine these associations in this systematic review.

\section{Author Responses:}

The findings: "The elderly and individuals with pre-existing medical conditions such as high blood pressure, heart and lung disorders, diabetes, and cancer are at greater risk of experiencing severe COVID-19 symptoms" was deleted since it is not supported by the data and the authors did not measure the associations. 
8. The Conclusion and Discussion need substantial revision focussing on the findings of this systematic review only. The accuracy of rapid antigen tests remains debatable; therefore, unless not available, RT-PCR should be preferred as the first-line strategy.

\section{Author Responses:}

'The accuracy of rapid antigen tests remains debatable; therefore, RT-PCR should be preferred unless not available as the first-line strategy' was put in the first line of the conclusion.

9. The authors need to expand upon the statistical analysis, as in what descriptive statistics were used for subgroup analyses:

\section{Author Responses:}

The authors did not use statistical analysis, for instance, a meta-analysis, because quantitative data such as Odds ratio, p-value, etc. were not supported in the articles selected.

Competing Interests: No competing interests were disclosed

\section{Comments on this article}

\section{Version 1}

Reader Comment 22 Jan 2022

Rahayu Lubis, Universitas Sumatera Utara, Medan, Indonesia

This article is useful and provides information about the COVID-19 early detection test but does not discuss the cost of the test.

Competing Interests: No competing interests were disclosed. 
The benefits of publishing with F1000Research:

- Your article is published within days, with no editorial bias

- You can publish traditional articles, null/negative results, case reports, data notes and more

- The peer review process is transparent and collaborative

- Your article is indexed in PubMed after passing peer review

- Dedicated customer support at every stage

For pre-submission enquiries, contact research@f1000.com 